\title{
Whether integrating refining and petrochemical business can provide opportunities for development of petrochemical industry in Serbia
}

\author{
Zoran M. Popović ${ }^{1}$, Ivan Souček ${ }^{2}$, Nickolay M. Ostrovskii ${ }^{3}$, Ozren J. Ocić ${ }^{1}$ \\ ${ }^{1}$ Institute of Chemistry, Technology and Metallurgy, University of Belgrade, Belgrade, Serbia \\ ${ }^{2}$ University of Chemistry and Technology (UCT), Prague, Czech Republic \\ ${ }^{3}$ HIPOL a.d., Odžaci, Serbia
}

\begin{abstract}
Since the beginning of 90 s of last century both the petroleum industry and petrochemical industry have operated in difficult circumstances. In particularly, margins of petroleum and petrochemical industry were exacerbated during global economic crisis in 2008-2009 years. At that time, as one option that could be the solution, the global analysts had started to more intense investigate the benefits of Refining-Petrochemical Integration. Shortly afterwards, more and more petroleum refineries and petrochemical manufacturers began to see the future in this kind of operational, managerial, marketing and commercial connection. This paper evaluates, in particular, the achieved level of integration of refinery and petrochemical businesses in Central and South-Eastern Europe. Specifically, the paper identifies current capabilities and future chances of linking this kind of integration between Serbian refining and petrochemical players. The viability of integration between possible actors and benefits of every single refining-petrochemical interface in Serbia depend on many factors, and therefore each integrated system is unique and requires prior serious cost benefit analysis.
\end{abstract}

Keywords: refining-petrochemical integration, serbian petrochemistry, development goals, cost-benefit analysis.

PROFESSIONAL PAPER

UDC 665.71.001.6(497.11):658

Hem. Ind. 70 (3) 307-318 (2016)

doi: 10.2298/HEMIND150122037P

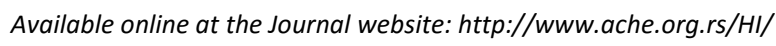

Already for a decade and more there is not prognostic study on development of the petroleum industry and/or petrochemical sector (or related published paper, presentation at the conference, etc.) that did not take into consideration the integration of refining and petrochemical business as a crucial global trend. There are already $4-5$ years how this theme is subject of discussions in Serbia also, practically from the moment of recognizing the additional potential for business activities between petroleum refinery in Pančevo of JSC "NIS" and neighboring petrochemical enterprise JSC "HIP-Petrohemija". Slowly, as time went on, the professional community has begun to notice the integrative potential that possesses some other petrochemical plants in Serbia.

During last several months, the possible deeper involvement of "NIS" in "HIP-Petrohemija" has been discussed intensively by newspaper articles and Internet blogs expecting/willing/proposing/supporting that it happens upon strong interest of minority "NIS" shareholder, which is Republic of Serbia. Instead of that, "NIS" clearly declared about not having interest

Correspondence: Z.M. Popović, Institute of Chemistry, Technology and Metallurgy, University of Belgrade, 11000 Belgrade, Njegoseva 12, Serbia.

E-mail: z.popovic@ihtm.bg.ac.rs

Paper received: 22 January, 2015

Paper accepted: 19 June, 2015 for taking over "HIP-Petrohemija" but supporting its development and "softening" commercial relationship.

In this paper we do not have pretension to support an unconditional merge of petroleum refining and petrochemical businesses in Serbia, but we wish to identify in one place and in the most concise form all of the elements that a serious Cost-Benefit Analysis (CBA) which treats integration of refinery and petrochemical facilities has to take into account. We believe that including and quantifying of all those elements in CBA might be a significant shift from the previous arbitrary estimates. Besides, it should be mentioned that in Serbia there are two other petrochemical enterprises with the potential for economically efficient integration with existing and planned production activities of the "NIS" these are the companies JSC "MSK" Kikinda and JSC "Hipol" Odžaci.

\section{Drivers for refining and petrochemical integration}

Petroleum industry works in difficult circumstances since the beginning of $90 \mathrm{~s}$ of last century, what is exacerbated during global economic crisis in 2008-2009 years. Factors that determine or direct the development of refining in Europe are: stagnation or decline in consumption of motor fuels, trend in motor fuel consumption which favours diesel over gasoline (which means surplus of FCC, Fluid Catalytic Cracking, gasoline), market fragmentation, environmental regulations, global competition (especially from regions with 
high rates of economic growth, such as Asia and Middle East), and in comparison with the rest of the World (in average) [1]:

- older production facilities (higher maintenance costs, lower energy efficiency),

- $\quad$ smaller dimensions of installed process plants (higher fixed operating costs), and

- $\quad$ higher labour costs.

Significant increase of the consumption of diesel fuel at the expense of gasoline, as well as a broader substitution of heavy fuel oil as an energy resource in petroleum refineries with natural gas (driven by European directives related to reduction of sulphur emissions), have been the main drivers of structural changes that occurred during last decade in the European demand of petroleum products. The question of surplus gasoline fractions partly have been solved through cooperation with petrochemical industries where naphtha is used as a raw material (mostly in Europe), or through export (mainly to the North American market, where there is a continuous shortage of gasoline). Using of natural gas as a fuel for use in petroleum refineries releases a solid amount of a naphtha's waste gases, which can be then used as raw material for the production of hydrogen and a series of basic petrochemicals (ethylene, propylene, para-xylene ...). The survival of the European petroleum refineries is conditioned by raising the efficiency and reaching the competitiveness in comparison to the modern refineries that are located in regions with high rates of economic growth. Approach includes technological and organizational-managerial optimizations of the existing production processes and commercial activities.

The specificity of the petrochemical sector is a highly cyclical character of this business influencing its profitability, with cycles that capture phase of prosperity (period with high margins impacting investment decisions and business development) and phase of recession (period of low, even negative, margins impacting closure of the least efficient capacities). The height and length of the amplitudes in these cycles primarily depends on the imbalances of supply and demand of petrochemical commodities, as well as on the occasional disharmonies in vertical integration starting from primary feedstocks (naphtha, ethane, natural gas, coal, and from recently also a shale gas and bio-feedstocks), via basic petrochemicals and petrochemical intermediates up to the final products (polymers, elastomers, synthetic resins, chemical fibers, surfactants,...), usually lasting 4-7 years. However, increasingly important factor is also unpredictable impacts of global or regional economic crisis, armed conflicts and other geopolitical disturbances, as well as natural disasters (unfortunately, more and more frequently), and consequently the dynamics of cycles of prosperity and recession is less predictable [2].

All analysts agree that global demand of petrochemical commodities will continue to grow, but very differently by regions. Leadership in demand and production has already shifted to China and other Asian countries and most new projects are developing in this region (using economy of scale and high growth of regional demand).

In Europe, some spectacular development of petrochemical industry is not expected, mainly due to stagnation of Western European economy. Within the global petrochemical industry, the capacities for production of naphtha-based olefins will continue to be in the most unfavourable economic position, and unfortunately the facilities of this type are characteristic for Europe. Manufacturers will strive to maximize production from other advanced resources, such as condensate of natural gas, coal derived liquid hydrocarbons and shale gas.

Overall, petrochemical companies throughout the world are restructuring, consolidating and implementing domestic and global strategies to improve profitability and contend with forecast economic changes, particularly in Europe where growth is lagging.

The last 5-6 years, starting with the outbreak of the global economic crisis, the manufacturers of petroleum products and petrochemicals in Europe were operating with low margins and modest rates of capacity utilization. The competition of non-European manufacturers is growing, mainly due to economy of scale, lower labor cost and access to cheaper raw materials. In the last two years there has been a certain recovery of profitability culminating in the beginning of 2015.

One option for a possible "ironing" the amplitudes of profitability in the petrochemical industry, and the specific weaknesses that characterize both refining and petrochemical sector in Europe, is integration of business activities in the field of petroleum products and petrochemicals manufacturing (called usually "RefiningPetrochemical Integration" or "Refining-Petrochemical Interface Optimization").

Other drivers for refining and petrochemical integration include [2]:

- Reliability and security of feedstock supply with less transport cost;

- Higher possibilities for processing and re-processing of hydrocarbon streams both from refinery and petrochemical plant;

- Increased use of natural gas and own fuel gases as fuel in petroleum refineries and petrochemical manufacturing plants (substitution of heavy fuel oil);

- Lowering the costs per unit of final product (mainly fixed costs, but very often variable costs also); 
- More flexibility in storing/transporting off core products and by-products;

- More outlets for high-value by-products;

- Energy savings in well-integrated hydrocarbon processes;

- Reduced needs for inventories, and therefore a significant savings in storage requirement;

- Significant reduction in shared utilities system, less variable costs;

- Supply chain optimization resulting in faster delivery of products and optimum distribution;

- Centralized support services, engineering, maintenance, laboratory, security, finance, human resources, etc., less fixed costs;

- Possibility to reach higher cash margin.

Indeed, the primary integration driver is competitiveness. Desire for higher profitability in an increasingly competitive market pushes petroleum refining and petrochemical companies to innovate ways to squeeze out costs and capture new opportunities.

The refining-petrochemical interface is primarily centered in the European refineries to take advantage of proximity to feedstock source and to get cost benefits by a joint infrastructure.

There are many examples that indicate that the refinery-petrochemical integration will continue to be crucial trend in the future. Management of the major Italian oil company "Eni" sees [9] the future of refining business in Europe through a focus on four activities: refining and petrochemical interface, increase of flexibility, achievement of technological superiority and an increase in efficiency. Sibylle Tinhof, spokesman of the major Austrian oil company "OMV", said [10] that the company will continue to be interested only in those refineries that are integrated with petrochemical business. Aslam Moola, New Business Development Manager in "Shell Chemicals", says [6] that most of the integration value comes from directing hydrocarbons to the highest-value application, irrespective of traditional refining-chemical boundaries. He says also that secondary or by-product streams from refining units may have their highest value as feedstock for chemical units, likewise, by-products from chemical units may be most cost-effective as refinery feeds or fuel blending components.

\section{Benefits of Refining and Petrochemical Integration}

Benefits of refining and petrochemical integration (RPI) are measurable both on the costs side and on the revenues side:

a) RPI means operating the activities under the same management with common objectives to optimize operations in the business or geographical areas which are in the phase of saturation or declining and also those which are in the prosperous phase, and develop new projects in the fast-growing areas. Putting together refining and chemicals teams creates synergies and generates new ideas, which brings a lot of innovation.* Main synergetic benefits that come through increased flexibility in operations and innovative technological development are:

- Increased production of light olefins (particularly propylene) and BTX (Benzene-Toluene-Xylene fraction) range aromatics from vacuum gas oil in an integrated petroleum refinery for use as petrochemical feedstock relative to maximum gasoline;

- Opportunity to convert this lower-value intermediate product from light cycle oil from the FCC unit in an integrated petroleum refinery into high-value BTX aromatics for petrochemical production (particularly para-xylene and benzene);

- Conversion of heavy distillate and vacuum gas oil feeds in an integrated petroleum refinery into maximum Naphtha for subsequent reforming, or a mixture of Naphtha and premium quality jet and diesel streams for transportation fuel blending;

- Opportunity to increase olefin production in an integrated petrochemical plant by improving the quality of the cracker feed and improving the ethylene/propylene selectivity of the product slate (these improvements are achieved in an integrated refiningpetrochemical complex pre-processing Naphtha separating a n-paraffin rich cracker feed stream from an isoparaffin rich, high octane stream for gasoline blending);

b) RPI provides additionally a number of key synergistic opportunities through increased integration of streams and flexibility in operations. These possibilities in an integrated refining-petrochemical complex are diverse and include:

- Stabile supply of low-cost feedstocks through advanced adaptation of an Ethylene Plant to allow valorization not only Naphtha but also Refinery gases, LPG (Liquid Petroleum Gases, usually Propane-Butane) and some heavier refinery streams;

- Economics of kerosene's fraction could be significantly increased by the extraction of normal paraffin and production of their derivatives within integrated petrochemical complex;

- By-products from integrated petrochemical plants could provide streams for fuels blending or cheaper chemical components to be used in economically justified production of motor fuels under the new standards;

- Recovery and re-use of Hydrogen through the integrated complex to reduce net Hydrogen production costs;

c) The substitution of heavy fuel oil as refinery fuel by natural gas increases the efficiency of the integrated

\footnotetext{
*Although, as aforesaid, there are significant differences in business philosophy between these two professions, that occasionally are causing the negative consequences.
} 
refining-petrochemical system in a several ways. Use of natural gas as a refinery fuel [7]:

- releases a solid quantity of naphtha, which is used as a raw material and fuel in steam reforming (hydrogen production) and as fuel in gas turbines - the released naphtha is then valorized in a much more profitable manner through production of light olefins or aromatics;

- provides the opportunity for recovering valuable components from waste gases, such as hydrogen, ethane, ethylene, propylene and propane;

- allows the complete vacuum residue to be processed by Bottom-of-the-Barrel Technology, for example in the "delayed coker", and thus to increase the yield of distillate (diesel fuel + naphtha) at the expense of heavy fuel oil for 10-12\%. Integrated system sends generated naphtha in the petrochemical pyrolysis. Moreover, the waste gases from "delayed coker" contain a solid amount of propylene;

- provides the following resulting bonuses: reduced production of heavy fuel oil, increased production of diesel fuel, increased availability of feedstock to produce olefins and aromatics, and reduced $\mathrm{CO}_{2}$ emissions [8].

d) In today's competitive and volatile business environment, an integrated refining and petrochemical complex offers considerable opportunities for enhancing operational efficiencies and unique synergies that reduce not only variable material operating costs, but also the variable costs of energy and other utilities, then many items of the fixed costs, and also capital costs and working capital expenditures:

- savings in logistics costs are particularly significant and important. Some analyzes have shown that the reduction of logistic costs by $10 \%$ within the supply chain of raw materials/intermediates in chemical production increases profitability by $6-8 \%$ (for example, reduce of administration costs by $10 \%$ increases profitability by only $2-4 \%$ ).

- shared utilities systems and storage capacities, and opportunities for hardware integration, results in savings of capital expenses. Reduced needs for inventories reduces amount of required working capital.

e) Finally, RPI generates opportunity for increasing the overall revenues through the production of high quality transportation fuels and high-value petrochemical intermediates and/or end-products.

Should be mentioned that a previous list of benefits does not contain item „re-processing of the by-products from petrochemical complex to the various petrochemical derivatives of higher-value". Why is that? This kind of investment activity undoubtedly increases overall revenue and therefore is practically mandatory for every modern petrochemical complex, whether it is integrated or not. Except in Serbia, as will be seen later in this paper.

\section{Does refining-petrochemical integration guarantees improved economic performance?}

Still, not everything is so simple and unambiguous.

Some conservative analysts of petroleum industry still dispute the benefits of refining-petrochemical integration by the fact that periodic recessions very often pushed petrochemistry into such a profound losses that are unimaginable for the petroleum refining industry. But just in significant cyclicality of the petrochemical business lies a competitive advantage of refining-petrochemical integrations. To put it simply, if the joint "benchmarking" is applied on a single integrated system of type "oil refinery + petrochemical complex", then in the prosperous periods of petrochemical business the management of an integrated system physically maximizes production of petrochemicals. Those petrochemicals are then marketed while achieving high profit rates that are unimaginable for refined petroleum products. Likewise, in recessionary periods of petrochemical businesses the management of an integrated system physically maximizes production of refined petroleum products whose placement is characterized by stable rentability.

On the other hand, some petrochemical analysts are of the opinion that availability of petrochemical production facilities of world-scale dimension is much more important for economic performance then backwards integration with a petroleum refinery.

Finally, the analysts from both sides agree that almost each individual refining-petrochemical integration was accompanied by some problems of objective or subjective nature, that might be considered as inevitable. The integration challenges that are noticed by the global analysts or managerial staff of petroleum refineries and petrochemical enterprises include:

1) increased complexity of integrated system;

2) limited operational flexibility;

3) conflicting planning objectives;

4) difference in business philosophies.

It is not justified to claim in advance that certain refining and petrochemical interface is sustainable. Each refinery-petrochemical integrated system is a case for itself and the estimation of its economic viability requires prior conducting of the very detailed cost-benefit analysis.

\section{Status of refining-petrochemical interface in gravitating region}

Petroleum refining and the petrochemical industry account for a major share of the world's energy and industrial markets. In many situations, these industrial sectors represent the economic backbone of national economy. 
With exception of Romania, all countries of Central and South-Eastern Europe are dependent on imports of crude oil and natural gas. On the other side, this region has a significant number of process plants to produce basic petrochemicals - finished commodities that are not profitable enough to withstand the high costs of transport to distant destinations, limited regional demand and relatively small installed capacities.

In the last two decades this region have responded on aforementioned weakness just through activities on integrating refining and petrochemical business, as it can be seen in Table 1 [3]. This kind of integration had allowed the conversion of the various available hydrocarbon streams from petroleum refineries and petrochemical plants into petrochemical derivatives of higher order derivatives - consequently, the domestic sales and profits had become larger.

Refining-Petrochemical Integration Index (RPII) defines the percentage of refinery's outputs that are delivered to further processing in petrochemical plants. For the refineries that operate in the region of Central and South-Eastern Europe this percentage ranges from $6 \%$ in the refinery company "SLOVNAFT" at the location Bratislava (Slovakia) to almost $30 \%$ in the „UNIPETROL GROUP“ Litvinov/Kralupy (Czech Republic). Virtually all the more serious petrochemical complexes in the region of Central and South-Eastern Europe are already integrated with refineries. The only non-integrated petrochemical capacities in region had the Croatian company DIOKI at locations in Zagreb and on the island Krk, but this company went bankrupt at the end of 2013.

Refining-petrochemical integrated systems are today successful companies in Poland, Slovakia, Czech Republic, Austria, Hungary and Romania. In this countries the goals on recovery of petroleum refining and petrochemical sectors were initially defined at the state level. Over time, the state was continuously reducing its stake in already profitable companies.

\section{Viability of Refining-Petrochemical Integration in Serbia}

\section{Possible actors of refining-petrochemical interface}

Record production of petrochemical commodities in Serbia was achieved 25 years ago, when all factories were still in social ownership (see Figure 1).

The privatization processes in chemical industry of Serbia have started in 1995, upon lifting of UN sanctions. These processes were interrupted by the NATO bombing campaign in 1999, during which the large facility for production of VCM (vinyl chloride monomer) in Pančevo was destroyed, and therefore two domestic PVC (Polyvinyl Chloride) plants, in Pančevo and Šabac, were left without the raw material.

Table 1. Refining-petrochemical Integration in Central and South-Eastern Europe

\begin{tabular}{|c|c|c|c|c|c|}
\hline \multicolumn{5}{|c|}{ Olefine/polyolefine production plants in CE \& SEE Region } & \multirow{2}{*}{$\begin{array}{l}\text { Remarks on petro- } \\
\text { chemical plants and } \\
\text { percentage of petro- } \\
\text { chemical products from } \\
\text { integrated capacities }\end{array}$} \\
\hline Company & Location & Country & $\begin{array}{c}\text { Polyolefines } \\
\text { integrated with } \\
\text { naphtha pyrolysis }\end{array}$ & $\begin{array}{l}\text { Olefines integrated } \\
\text { with streams of oil } \\
\text { refinery }\end{array}$ & \\
\hline OMV AG & Schwechat & Austria & Yes & Yes & $R P I I=9 \%$ \\
\hline Lukoil Neftochim Burgas & Burgas & Bulgaria & No & Yes & $\begin{array}{c}\text { Olefin plant is idle since } \\
\text { 2009, but PP plant works } \\
\text { integrated to refinery's } \\
\text { streams }\end{array}$ \\
\hline Dioki & Zagreb & Croatia & Yes & No & Bankrupted in 2013 \\
\hline Dioki & Omišalj & Croatia & No & No & Bankrupted in 2013 \\
\hline $\begin{array}{l}\text { Unipetrol Group, incl. Česká } \\
\text { Rafinerská }\end{array}$ & Litvínov/Kralupy & Czech R. & Yes & Yes & $R P I I=29 \%$ \\
\hline Mol Group - TVK & Szazhalombatha & Hungary & Yes & Yes & $R P I I=11 \%$ \\
\hline $\begin{array}{l}\text { PKN Orlen / Basell Orlen } \\
\text { Polyolefins }\end{array}$ & Plock & Poland & Yes & Yes & $R P I I=14 \%$ \\
\hline $\begin{array}{l}\text { Rompetrol Rafinare SA } \\
\text { PETROMIDIA Navodari }\end{array}$ & Navodari & Romania & Yes & Yes & - \\
\hline $\begin{array}{l}\text { Petrom Petrochemical Arges } \\
\text { (earlier Petrom SA Arpechim) }\end{array}$ & Pitesti & Romania & Yes & Yes & $\begin{array}{l}\text { Working status unclear } \\
\text { since } 2008\end{array}$ \\
\hline Petrom SA PETROBRAZI & Brazi & Romania & Yes & Yes & Not working since 2006 \\
\hline NIS - HIP Petrohemija & Pancevo & Serbia & Yes & No & $R P I I=17 \%$ \\
\hline Mol Group - SLOVNAFT & Bratislava & Slovakia & Yes & Yes & $R P I I=6 \%$ \\
\hline PETKIM Petrokimya SA & Aliaga & Turkey & Yes & Yes & - \\
\hline
\end{tabular}




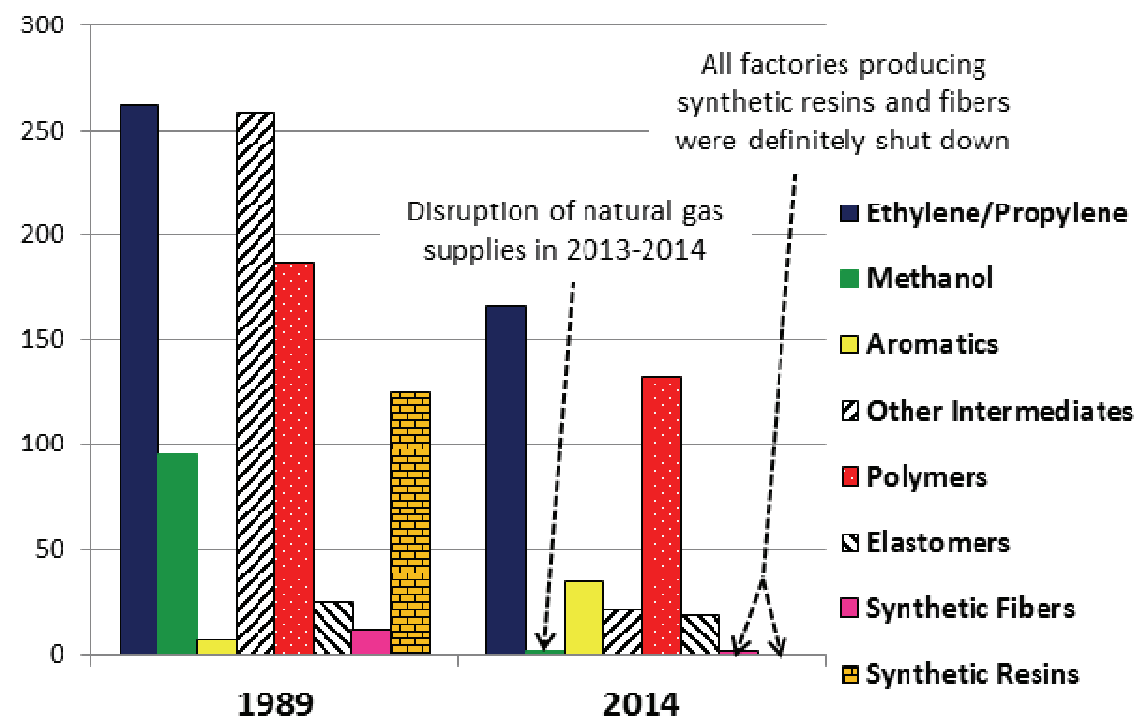

Figure 1. Production of petrochemical products in Serbia.

The transition processes in Serbian economy were accelerated since 2001, as the part of changes in Serbia after October 2000, but activities on privatization were carried out on such a disastrous way that practically complete basic chemical industry had been devastated. Let us mention here only several chemical companies that once were big and known even in frame of European scale, and nowadays even do not exist, such as "Zorka" Šabac, "Viskoza" Loznica, "Prvi Maj" Čacak, "Duga" Belgrade or "IHP" Prahovo, or a couple of them in bankruptcy and without promising future, such as "Župa" Kruševac or "Poliester" Priboj. In fact, many believe that corrupt or unprofessionally implemented privatizations have caused greater damage to Serbian chemical industry than UN sanctions and NATO bombing together [4].

Therefore, the possible actors in the eventual integration of refining and petrochemical business in Serbia are:

- ISC „NIS“ Novi Sad (or abbreviated: NIS), formerly national oil company and today a joint stock company majority owned by "Gazprom Neft". Its basic business activities include the exploration, production and processing of crude oil and gas, as well as the supply of a wide portfolio of petroleum products. It owns 2 refineries: Novi Sad and Pančevo. Petroleum refinery near the town of Pančevo has capacity to process 4.8 million tonnes per year of crude oil. In late 2012, NIS completed the first stage of Pančevo petroleum refinery modernization, which enabled the transition to the production of European-quality fuel, increased production of "white derivatives", and optimization of energy consumption. NIS also has activities in up-stream executing exploration and production of natural gas and crude oil in north-Serbian region (having advanced gas process plant located in Elemir).
The only three petrochemical companies that "survived" privatization "Made in Serbia" are:

- JSC "HIP-Petrohemija" Pančevo (or abbreviated: HIPP) is the largest petrochemical company in Serbia and organized as a joint stock company majority owned by the state of Serbia. Production complex in Pancevo was put into operation in 1979 . It owns capacity to produce around 250,000-350,000 t per year of petrochemical products: Ethylene as excess to needs of captive polyethylenes production, Propylene - "chemical grade", 1,3-butadiene as excess to SBR (styrene-butadiene rubber) needs, MTBE (methyl-tert-butylether), HDPE (high-density polyethylene), LDPE (low-density polyethylene), SBR, and around 100,000$-200,000$ tpy of by-products (pyrolytic gasoline, pyrolytic fuel oil, raffinate II) at production sites in Pančevo (southern Vojvodina) and Elemir (central Vojvodina). HIPP also operates two plants to produce HDPE pipes and fittings at location Luka Dunav, and HDPE granules near town of Crepaja.

Major feedstock: naphtha, supplied by the NIS Refinery Pančevo and/or imported. Major fuel: natural gas.

Current HIPP configuration and main interlinks with NIS are described on Figure 2.

Development programs:

a) De-methanolisation of Raffinate II for further upgrade within HIPP (or possibly also in refining sector); b) Co-cracking naphtha with LPG/n-butane; c) extraction of pentane and naphthalene from pyrogas and PFO, the by-products of ethylene Plant; d) Increasing the production capacity of HDPE from 90,000 to 110,000 tpy; e) Increasing the production capacity of LDPE from 54,000 to 70,000 tpy (through eliminating of bottlenecks); f) valorization of available ethylene and propylene (and benzene produced in the the NIS Refinery Pančevo) to another derivatives. 


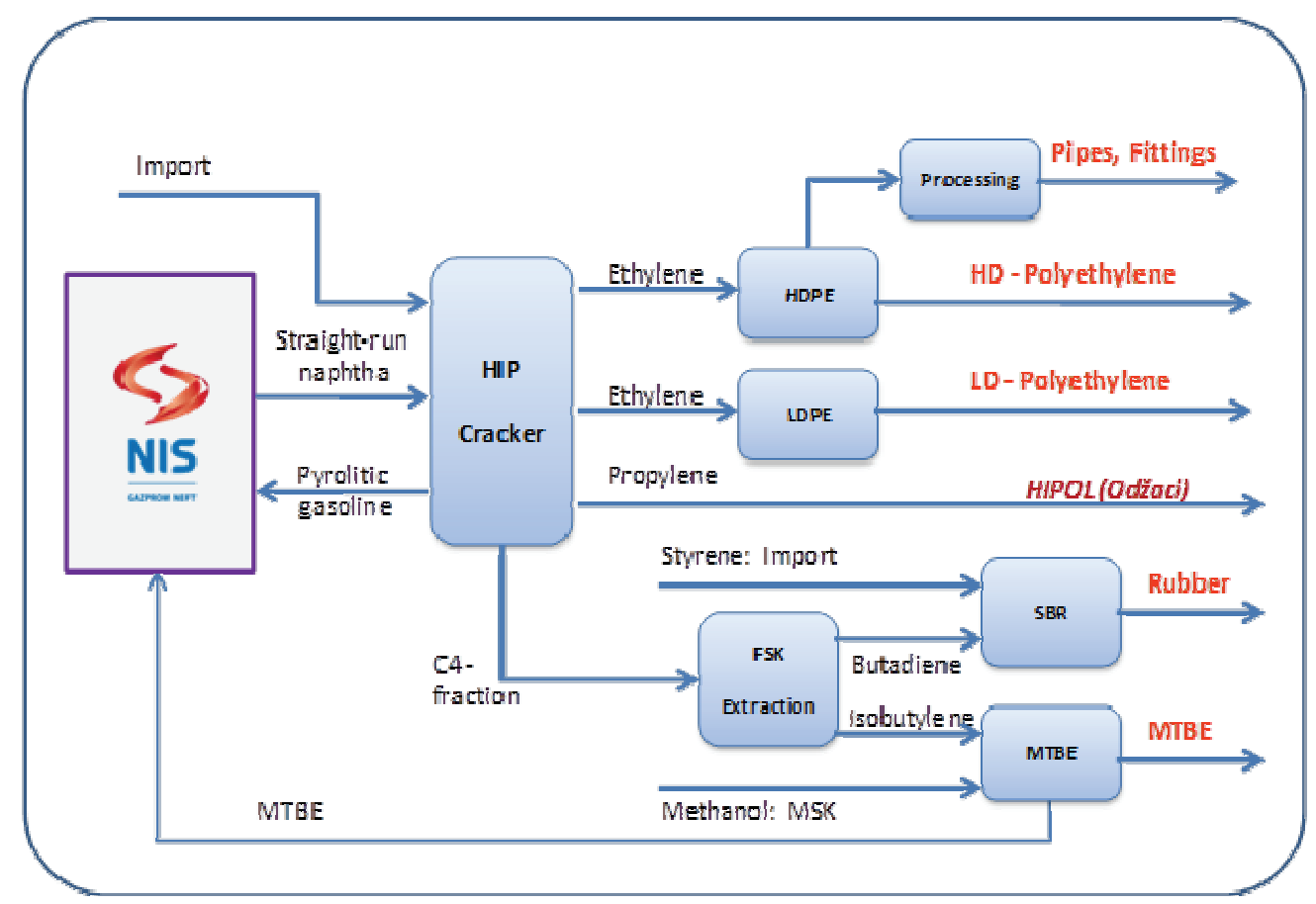

Figure 2. Current interface between NIS and HIP-Petrohemija.

- JSC "Hipol” Odžaci, a joint stock company majority owned by the state of Serbia. It is located on production site near town of Odžaci (western Vojvodina). Production complex was put into operation in 1983. It has capacity to produce 33,000 tpy polypropylene, 300-400 tpy atactic polypropylene (APP) and 20,000-30,000 tpy propylene - "polymer grade" (as excess to polypropylene plant's needs). Company also operates two distillation columns to process light naphtha $\left(C_{3}-C_{6}\right.$ fraction) and produce 50,000 tpy LPG and $\mathrm{C}_{5}-\mathrm{C}_{6}$ residue for its partner.

- Major feedstocks: propylene - "chemical grade" supplied by HIPP, propylene - "refinery grade" supplied by NIS and/or imported and Light Naphtha supplied by the company "Standard Gas", from its production and distribution center in the town of Odžaci. Major fuels: fuel oil and wood pellets.

Development programs:

a) Revamp of a third column in the Light Naphtha Distillation Plant (investment activity in progress which will enlarge output capacity to around 80,000 tpy LPG); b) Revamp of polypropylene plant, with enlarging of the capacity to 50,000 tpy (by adding a third reactor and a new 5 tph extruder); c) debottlenecking of propylene splitter; d) construction of special column for distillation of $\mathrm{C}_{5}-\mathrm{C}_{6}$ fraction in order to separate pentane and $\mathrm{C}_{6+}$ fraction; e) construction of facility to produce oxidized APP.

Current "Hipol" configuration and proposed development are described on Figure 3.

- JSC "Methanol-Acetic Acid Complex" Kikinda (or abbreviated: MSK) is a joint stock company majority owned by the Public Company "Srbijagas". It is located in the vicinity of the town of Kikinda $(6 \mathrm{~km}$ to the south of the Hungarian border and $25 \mathrm{~km}$ to the west of the Romanian border). Production complex was put into operation in 1987 . It has capacity to produce 200,000 tpy methanol, 100,000 tpy acetic acid (glacial), and 220,000 tpy oxygen.

Major feedstocks: petrochemical complex in Kikinda is originally designed to use domestic natural gas from the neighboring gas-fields, but in practice it was always consumed only imported Russian gas delivered by the company "Gasprom Neft". Major fuel: natural gas.

Development programs:

a) Polymeric emulsions plant to produce 20,000 tpy homo-polymeric and co-polymeric emulsions of vinyl acetate monomer (polyvinyl-acetates) and acrylates; b) Partial replacement of imported natural gas* with cheaper "sour gas"**; c) construction of the Cogeneration Plant for the combined production of steam, heat and electricity; d) plant to produce 25,000 tpy ethyl acetate and $n$-butyl acetate/isobutyl acetate; e) multipurpose process unit with capacity of 2,500 tpy for production of low-tonnage acetate esters, and service recovery of other oxygenated solvents; f) construction of dimethyl ether (DME) Plant.

*Natural gas is used in "MSK" Kikinda both as a feedstock and fuel.

**"Sour gas" is produced on gas-fields nearby Kikinda which are operated by NIS. It is reach in $\mathrm{CO}_{2}$, and therefore has low caloric value (not suitable for use as a fuel, but suitable for acetic acid production). 


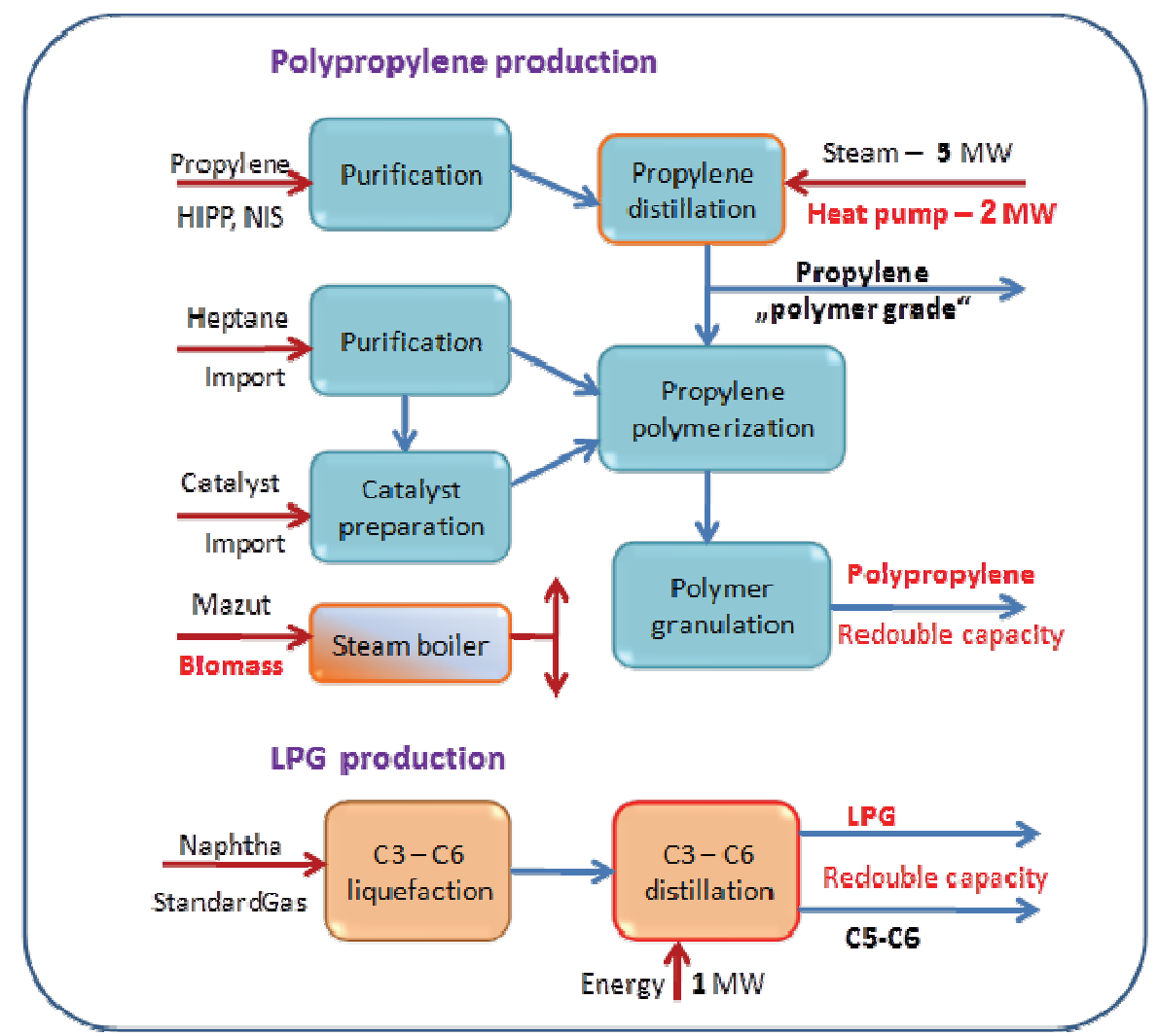

Figure 3. Current scheme of production processes in Hipol.

Current MSK configuration and proposed development are described on Figure 4.

According to European standards, the petrochemical companies HIPP and MSK belong to a category of medium-sized enterprises. These two manufacturers were lucky not to enter up to now into privatization processes "Made in Serbia“. When HIPP and MSK operate continuously and with a high utilization of available production capacities, and this will happen if stable supply of naphtha (HIPP) and natural gas (MSK) is provided, these two petrochemical manufacturers are generally ranked among the top five domestic exporters.

The company "Hipol" could be considered as relatively small manufacturer of basic chemical commodities. What this company makes exceptional is the fact that it is the only Serbian company in the field of base chemistry that has passed the process of privatization and still exists. And how difficult it was the best describes the business "Odyssey" which had lasted almost a decade including one cleavage of the company on its base and the processing part, two sales, two terminations of the privatization contract due to buyers' failure to fulfill contractual obligations, and two transformations into state ownership.

The only world-scale petrochemical capacity in Serbia is facility to produce 100,000 tpy of glacial acetic acid in MSK. The existing capacities to produce olefins, aromatics, methanol, polyolefins (LDPE, HDPE and PP) and elastomers (SBR) in Serbia are of small size according to the current economic standards. But maybe the main weakness is a fact that the domestic petrochemical manufacturers have not translated into industrial practice any development initiative in the last 30 years and have not introduced any significant capacity improvement (only HDPE capacity was modified from 60,000 to 90,000 tpy). Therefore, the base petrochemicals produced in Serbia today are internally converted into more profitable derivatives at low percentage (excl. ethylene and butadiene), almost as it was in the late seventies of the previous century. A smaller part of basic petrochemicals is sold in the country (as low profitable semi-finished goods), and the rest is exported (very often to very remote destinations, which implies a high share of transport costs in the selling price).

From the other side, an in accordance with European standards, the NIS-Petroleum Refinery Pančevo is an industrial facility of medium-size. The percentage of capacity utilization in this refinery is rather low, which influences the cost of refined products, esp. fixed costs. The process of recent modernization, significantly improved the competitive position of oil refinery in Pančevo. The structure of output streams was changed in the direction of adjusting the structure of assortment to market demands, and increase the share of highervalue derivatives along with achieving quality in accordance with European standards. On the other hand, 


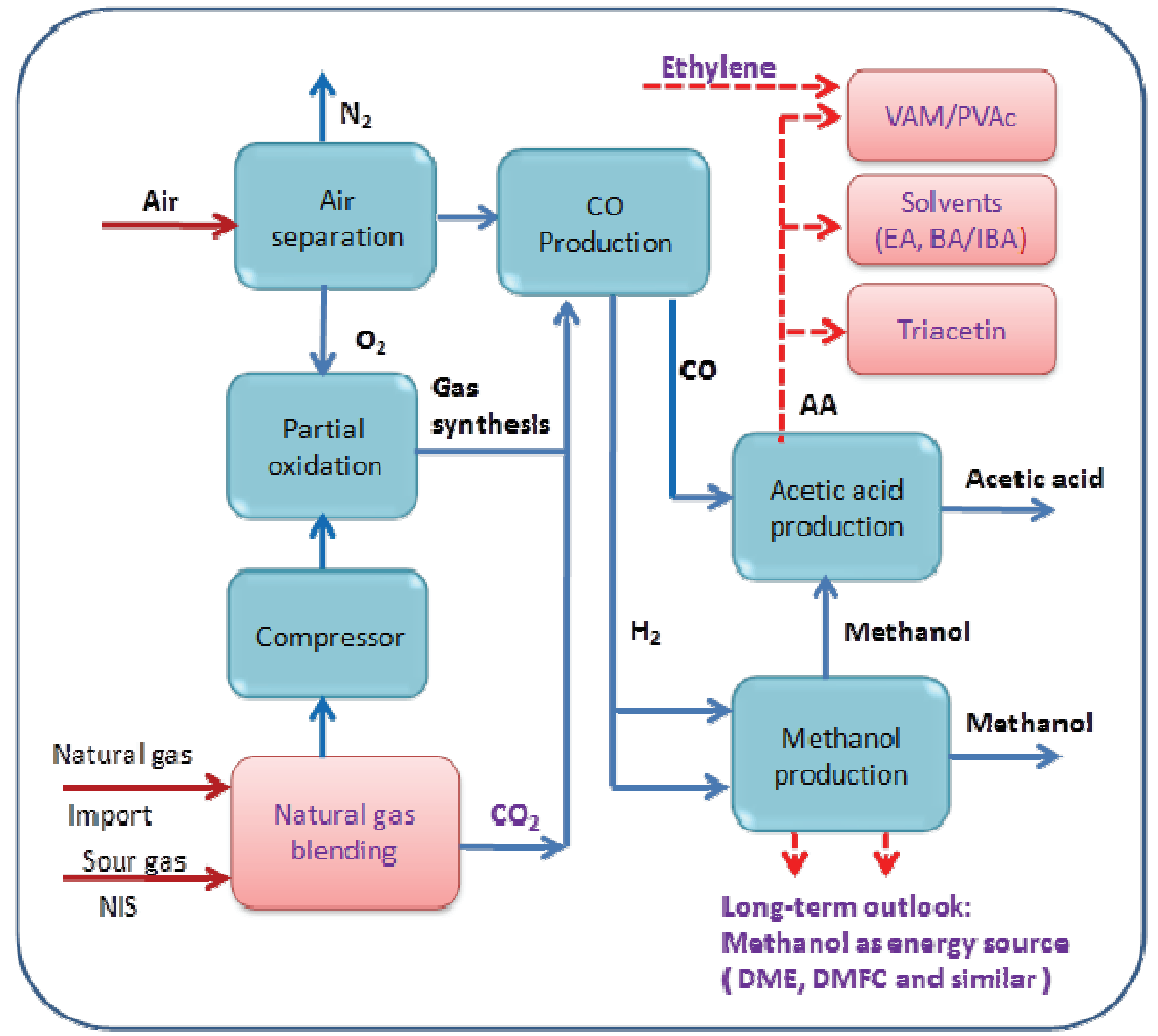

Figure 4. Current products scheme of MSK and its development projects.

however, still remains some disadvantages, or better say unused comparative advantages. Given the topic of this paper, here we primarily meant the economically inefficient use of some refinery's by-products or the non-optimal use of synergies in the exchange (already existing or technologically possible) of hydrocarbon streams with neighboring petrochemical complex HIPP.

\section{Current opporunities and future chances for refining- petrochemical interface}

All global analysts agree that today in Europe a petrochemistry based on the pyrolysis of naphtha economically cannot "survive" without valorizing all the core products and by-products in an optimal way. "An optimal way" is internal conversion of primary petrochemicals into profitable derivatives (polymers, elastomers, resins, fibers, speciality chemicals,...) to the highest possible degree. Unfortunately, the largest domestic petrochemical company, HIPP is just a rare example of an European petrochemical manufacturer which economically inefficiently uses a series of output streams of its production system (propylene, pyrolysis fuel oil, raffinate II). All of these output streams can be optimally valorized just within an integrated refinery-petrochemical system.

To these general weaknesses of the Serbian petrochemical industry, we can certainly add the low energy efficiency and surplus of employees.
There are some weaknesses that are specific to an individual company, such as unexplained fact that MSK for twenty years as by rule had not worked in the prosperous phases for the markets of methanol and acetic acid, and had worked mainly during periods of recession, when even the global leaders in production of these two petrochemicals were running their plants at a loss.

Almost all aforementioned weakness of refining and petrochemical sector in Serbia, however, might be in a way considered as drivers for the integration of refining and petrochemical business at national level.

However, according to the ChemSystems [5] categorization of the refining-petrochemical integrations achieved worldwide, the Serbian refining and petrochemical operators are currently integrated at level of $1^{\text {st }}$ generation, e.g., through only the simplest commercial relationships (sale or purchase of products and by-products, and certain integration of utilities between refinery and HIPP in very early stage), and without any additional joint considerations regarding finding the most optimal valorization of by-products or integration of available hydrocarbon streams, and introduction of new production processes based on that synergetic potential.

The specificity of integration between refining and petrochemical facilities in Serbia might be that not only there is a significant number of existing and potentially 
possible links between hydrocarbon streams of the NISOil Refinery Pančevo, on the one hand, and the three Serbian petrochemical companies, on the other hand, but as well a fact that exchange of material flows exist also between the individual chemical companies. This applies not only to current state in exchanging of hydrocarbon streams (propylene, methanol, MTBE, $\mathrm{C}_{5}-\mathrm{C}_{6}$ residuum) between Serbian petrochemical plants, but also to the matrix of all possible links between the material streams being generated by all the potential actors of R-P Interface in Serbia and which in the future might represent comparative advantage for the implementation of the several planned development programs.*

The main exchanged streams (or in future potentially could be) are shown on Figure 5:
- Py-gas (source of benzene and toluene).

- MTBE (possibly converted into ethyl-tert-butyl ether) in future.

- De-methanolised raffinate II (for further upgrade in refining sector).

$\mathrm{HIPP} \rightarrow \mathrm{NIS}:$

- Utilities and infrastructural services: existing HIPP Energy Plant capacity utilisation and NIS CAPEX optimisation; Waste Water Treatment Plant.

NIS $\rightarrow$ HIPOL:

- Propylene - „chemical grade“.

HIPP $\rightarrow$ HIPOL:

- Propylene - „chemical grade“.

$\mathrm{HIPOL} \rightarrow \mathrm{NIS}:$

- Atactic Polypropylene (possible future use in production of polymer modified bitumenes or abbre-

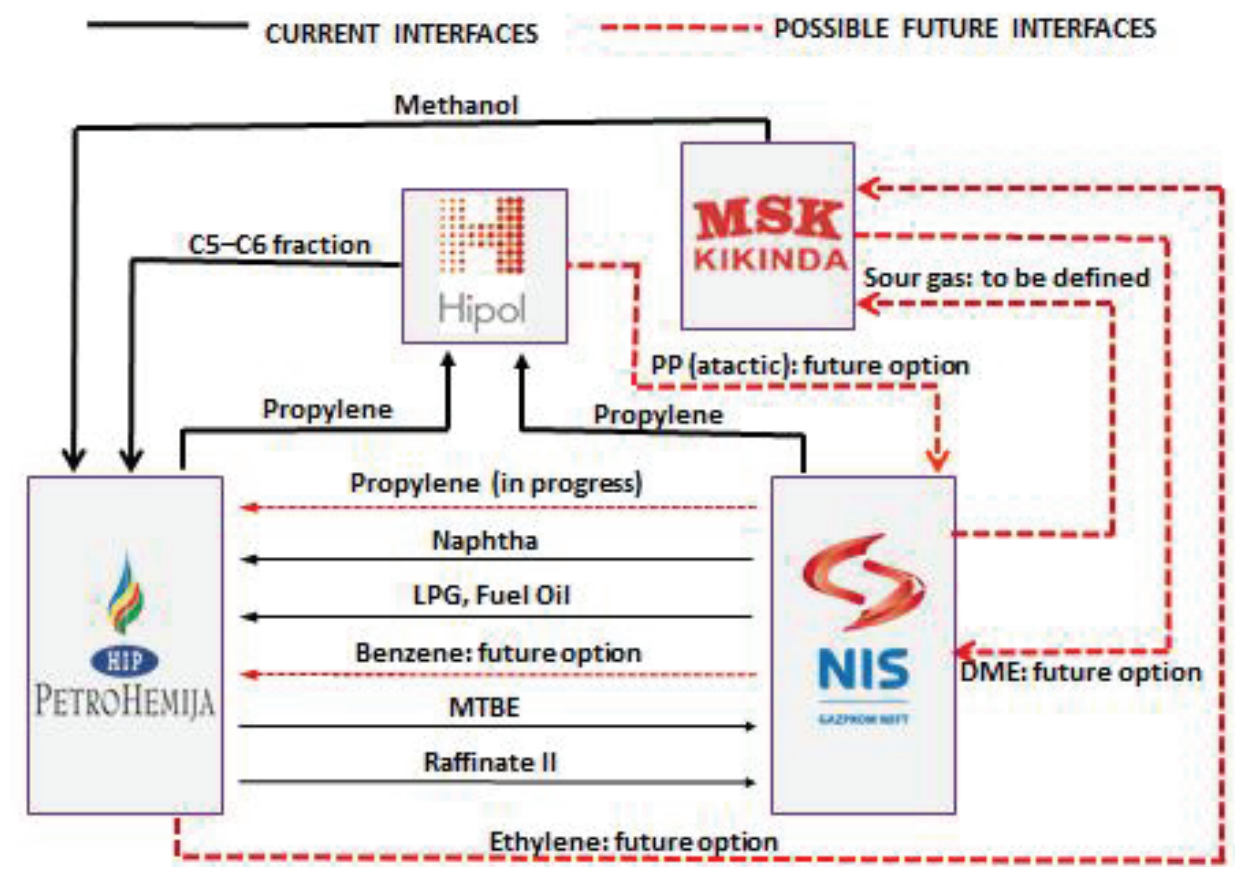

Figure 5. Refining-petrochemical Interface in Serbia: current and possible future integrations of hydrocarbon streams.

NIS $\rightarrow$ HIPP:

- Naphtha (preferably $70-105{ }^{\circ} \mathrm{C}$ fraction), LPG (preferably $n$-butane), fuel oil.

- Benzene (possible future option upon eventual construction of the facility to produce ethylbenzene/ /styrene within HIPP, or some other derivative to be defined).

- Propylene - „refinery grade“ (upon eventual construction of C3-Splitter within HIPP to produce propylene - „polymer grade“, which is an option in planning phase).

$\mathrm{HIPP} \rightarrow \mathrm{NIS}:$

*The viability of these development programs is already elaborated, or will be in the near future. viated PMBs, to be used in manufacturing of roofing membranes.

HIPOL $\rightarrow$ HIPP:

- $\mathrm{C}_{5}-\mathrm{C}_{6}$ residue (co-feedstock for pyrolysis in Pančevo).

HIPP - HIPOL - NIS:

- Optimisation of propylene balance and market value (through construction of the facility to produce „polymer grade“ propylene in HIPP or enlarging the PP production capacity in "HIPOL“ or a construction a new PP plant in Pančevo.

NIS $\rightarrow$ MSK:

- "Sour gas" as feedstock for production of methanol/acetic acid (future option for substitution of imp- 
orted natural gas by gas rich in $\mathrm{CO}_{2}$ and produced by NIS on the gas-fields nearby Kikinda).

$$
\text { MSK } \rightarrow \text { NIS: }
$$

- DME for blending into LPG (possible future option upon eventual construction of the facility to produce DME from methanol within MSK).

MSK $\rightarrow$ HIPP:

- Methanol (for MTBE production in Elemir). HIPP $\rightarrow$ MSK:

- Ethylene (possible future option upon eventual construction of the facility to produce Vinyl Acetate Monomer within "MSK“).

It should be mentioned that on the long-term basis there are a number of additional development concepts based on RPI to be analyzed and evaluated.

Anyhow, what is stated in this paper clearly shows that there is potential for achievement of positive synergies between Serbian actors in refining-petrochemical integrations. Based on this potential and conducting all necessary cost-benefit analysis, the current not so shiny situation regarding profitability of petroleum refining and petrochemical business in Serbia might be converted into positive direction. This goal requires closer cooperation between all entities and their major shareholders (keeping fair market related conditions which takes into account product quatation and their import/export parity and considering further increase of installed capacities for selected products).

\section{CONCLUSIONS}

As it is today in almost all spheres of life, the main motive for refining and petrochemical interface is possibility to enhance profit. Since refining-petrochemical integration is no longer just a theoretical postulate, but as business operation already has a serious history in industrial practice and the corresponding results in terms of enlarged profits, the critics are less and less. Actually, they no longer have a question of whether integration should be implemented, but only which degree of integration is economically optimal.

It is a fact that each integrated system is the story for itself, and it is also a fact that the domestic petrochemical companies have a number of objective and subjective weakness, but it is also a fact that so far in Serbia up to now no one has conducted a comprehensive CBA of synergies generated throughout integrating refining and petrochemical business. The complexity of task is increased by the fact that the viability of the RPI in the specific case of Serbia must be calculated as a mixture of economic and social (national) interests.
Namely, it is necessary to define the lowest common denominator:

- for the purely economic interest of the majority owner of the refinery business in Serbia, the Russian company "Gazprom Neft",

- for the interests of foreign companies that are seen as potential strategic partners (willing to extend existing domestic petrochemical capacities, to develop the brand new facilities to produce more sophisticated petrochemical derivatives, and possibly to participate on deeper implementation of Refining-Petrochemical interface optimization), and

- for the interest of Serbian Government to keep operational two economic backbones of national economy.

It is a task that requires urgent implementation, especially because all the predictions say that in the period after the year 2016 the European petrochemical industry is entering into a more prosperous phase.

\section{REFERENCES}

[1] I. Souček, Z. Popović, O. Ocić, Refinery and Petrochemical Interface, Refining and Petrochemical Round Table at 15th Central and Eastern European Refining and Petrochemical Conference - WRA, Bucharest-Romania, October 23-25, 2012.

[2] Z. Popović, I. Souček, O. Ocić, N. Ostrovskii, S. Adžić, Refining and Petrochemical Interface. Case study: HIP Petrohemija - NIS, Energija, Ekonomija, Ekologija 16 (2014) 237-242.

[3] I. Souček, Meeting experts, Global Report on Refining and Petrochemical Integration, World Refining Association (2014) 12-13.

[4] Z. Popović, D. Marinković, Revitalization and development of production of highly processed derivatives: A precondition for survival Serbian petrochemical industry, Istraživanje i projektovanje za privredu 7 (2009) 33-43 (in Serbian).

[5] ChemSystems' Refinery Petrochemical Interface, 1997 (http://www.chemsystems.com).

[6] A. Moola, Exploiting Refinery and Petrochemical Integration, 2014 (http://www.shell.com).

[7] T. Taraphadar, P. Yadav, M.K.E Prasad, Natural gas fuels the integration of refining and petrochemicals, Petrol. Tech. Q. 17 (2012) 1-9.

[8] S. Ratan, R.van Uffelen, Curtailing refinery $\mathrm{CO}_{2}$ through $\mathrm{H}_{2}$ plant, P.T.Q. Gas (2008) 19-23.

[9] M. Maugeri, The Future of Refining in Europe, 2014 (http://www.eni.com).

[10] S. Tinhof, Austria's OMV in negotiations to divest Bayernoil stake, August 21, 2013. (http://www.icis.com/ /resources/news/2013/08/21/9699409). 


\section{IZVOD}

\section{DA LI INTEGRISANJE RAFINERIJSKOG I PETROHEMIJSKOG BIZNISA PRUŽA MOGUĆNOST ZA RAZVOJ PETROHEMIJSKE INDUSTRIJE U SRBIJI}

Zoran M. Popović ${ }^{1}$, Ivan Souček ${ }^{2}$, Nikolaj M. Ostrovski ${ }^{3}$, Ozren J. Ocić ${ }^{1}$

${ }^{1}$ Institut za hemiju, tehnologiju i metalurgiju, Univerzitet u Beogradu, Beograd, Srbija

${ }^{2}$ University of Chemistry and Technology (UCT), Prague, Czech Republic

${ }^{3}$ HIPOL a.d., Odžaci, Srbija

\section{(Stručni rad)}

Industrija prerade nafte i petrohemijska industrija posluju u otežanim uslovima još od početka devedesetih godina prošlog veka. Posebno veliku eroziju profitnih stopa su ova dva industrijska sektora doživela tokom eskalacije globalne ekonomske krize u 2008. i 2009. godini. Upravo u tom periodu, kao jednu od mogućih solucija oporavka globalni analitičari počinju da intenzivnije elaboriraju benefite integrisanja rafinerijskog i petrohemijskog biznisa. Nedugo zatim svoju budućnost u ovoj vrsti proizvodno-poslovnog povezivanja počinje da vidi sve više i više naftnih rafinerija i petrohemijskih kompleksa. Ovaj rad evaluira dostignuti nivo integrisanja rafinerijskog i petrohemijskog biznisa u Centralnoj i Jugoistočnoj Evropi. Potom se u radu identifikuju aktuelne mogućnosti i buduće šanse za povezivanje ovakvog tipa u Srbiji. Održivost integrisanja među potencijalnim domaćim akterima i isplativost svakog pojedinačnog povezivanja rafinerijskog i petrohemijskog biznisa zavisi od mnogo faktora, te realizacija svakog integrisanog sistema predstavlja slučaj za sebe i zahteva prethodno sprovođenje veoma ozbiljnih tehnoekonomskih analiza.
Ključne reči: Integrisanje rafinerijskog $\mathrm{i}$ petrohemijskog biznisa - Srpska petrohemija • Razvojni ciljevi • Tehnoekonomska valorizacija 